\title{
INTEGRATION OF CHARACTER VALUES IN LEARNING PANCASILA AND CITIZENSHIP EDUCATION (PPKN) IN STRENGTHENING THE MORAL OF THE NATION
}

\author{
Andi Tenri Yeyeng ${ }^{1}$ \\ Muchtar Lutfi ${ }^{2}$ \\ Muhammad Yaumi ${ }^{3}$ \\ Muhammad Saleh Tajuddin ${ }^{4}$ \\ Universitas Islam Negeri Alauddin Makassar ${ }^{1,2,3,4}$
}

\begin{abstract}
This paper discusses the integration of character values in Pancasila and Citizenship Education (PPKn) subject. This integration needs to be done considering the increasing number of national problems, such as brawls, drug abuse, corruption, money politics, abuse of authority, and so on. Several character values such as religious values, love for the country, democracy, honesty, hard work and others need to be integrated into PPKn learning. So far, PPKn studies have only been studied with regard to cognitive aspects, while affective and psychomotor aspects have not been given sufficient space to improve student character scores. Strategic and methodological rarities are needed such as planning, implementing and evaluating PPKn learning. As a recommendation to every educator to improve their knowledge, skills, and methodological abilities such as workshops and further study.
\end{abstract}

Keywords: Integrity; Character Values; Pancasila; Civic Education; Nation Moral

\section{INTRODUCTION}

Character values have once become a hot topic since it was declared a national movement in the form of a declaration of "National Culture and Character Education" at a national workshop organized by the Ministry of National Education on January 14, 2010. ${ }^{1}$. This was reaffirmed by former president Susilo Bambang Yudoyono in his speech, demanding character development in the field of education on the commemoration of National Education Day 2 May 2010. ${ }^{2}$ The trend regarding character values has received a response from various parties, especially educators who care about various national issues in Indonesia. A discussion about the need for character values to be implemented in the younger generation raises due to a series of facts about the low morality of the nation initiate.

Corrupt practices that are detrimental to the nation, immoral political practices, businesses that are detrimental to society, selective law enforcement, murder cases, brawls among students, to cases of violence in schools, and many more. This condition encourages serious efforts to implement character values in schools, because if this continues, the Indonesian people will lose generations of Indonesian character. The

${ }^{1}$ Darmiyati Zuchdi, et.al, Pendidikan Karakter dengan Pendekatan Kompehensif (Cet. 1; UNY Press, 2010), p. 1.

${ }^{2}$ Winarno Narmoatmojo, Pendidikan Nilai di Era Global (Paper Presented in Regional Seminar "Implementasi Pendidikan Nilai di Era Global" 22 September 2010 in Postgraduate Building of UNISRI Surakarta. 
country and nation will gradually be destroyed and become a nation lack in character and humiliated by other countries. One of the approaches to anticipate this problem is to provide character values or also popular as character education to students through learning Pancasila and Citizenship Education (PPKn). Integrating character values in PPKn learning is an effective effort to overcome national problems in the future.

\section{METHOD}

This paper used a research method with qualitative descriptive research type. This research was based on a phenomenological approach, which was a research approach using Edmund Husserl's research theory. ${ }^{3}$ Through this approach the authors saw the general phenomena of national problems in Indonesia such as juvenile delinquency, brawls between students, drugs, sex abuse, and others. Data obtained from various sources in the form of books, national and international journals, newspapers and the internet. Existing data were analyzed through descriptive analysis through analyzing, defining, describing, and summarizing various national problematic phenomena. ${ }^{4}$ The results of this research then will be recommended as solutions to the existing problems.

\section{III.CHARACTER VALUES AS A FOUNDATION OF THE MORAL OF THE NATION}

Values and character are two aspects that have a fairly comprehensive meaning as a basis for strengthening the nation's morals. Zakiyah Darajat defines value as a part of belief or feeling that is believed to be an identity that can influence patterns of thought and feeling, as well as behavior. ${ }^{5}$ A similar opinion was expressed by Sidi Gazalba, views that value is not something that is concrete in nature, but something that is abstract. Everything that is still in the stage of understanding what is wanted and unwanted does not include something that is factual, but the issue of right and wrong will demand empirical proof. ${ }^{6}$ The opinion of the experts mentioned above clearly defines value as something abstract and contained in the human conscience that produces positive behavior that guides human life.

According to Chabib Toha, that value is a characteristic inherent in something (belief system) that has been associated with the subject that gives meaning (human who believes). ${ }^{7}$ Bertens stated the following characteristics of values; 1 ) the value is related to the subject, if there is no subject to judge then there is no value, 2) the value is present in a practical context where the subject wants to make something, 3) the values contain the properties that are "added" by the subject to the characteristics - properties possessed by objects. ${ }^{8}$

Meanwhile, character is related to basic human nature. The Ministry of National Education (Kemendiknas) defines character as a person's character, manners or morals, or personality which is used as a basis in the way of seeing, thinking, behaving, and acting

\footnotetext{
${ }^{3}$ Sadruddin Bahadur Qutoshi, Phenomenology. A Philosophy and Method of Inquiry, Journal of Education and Educational Development, Vol. 5, No. 1, June 2018, p. 215

${ }^{4}$ Joko Subagyo, Metode Penelitian dalam Teori dan Praktek(Jakarta: Renika Cipta, 1991), p. 202

${ }^{5}$ Zakiyah Darajat, Dasar-Dasar Agama Islam (Jakarta: Bulan Bintang, 2007), p. 260.

${ }^{6}$ Sidi Gazalba, Sistematika Filsafat, Buku Kedua: Pengantar kepada Teori Nilai (Jakarta: Bulan Bintang, 2002), p. 61.

${ }^{7}$ Chabib Toha, Kapita Selekta Pendidikan Islam (Yogyakarta: Pustaka Pelajar, 2006), p. 61.

${ }^{8}$ K. Bertens, Etika (Jakarta: PT Gramedia Pustaka Utama, 2005), p. 141.
} 
which differentiates it from others. ${ }^{9}$ Therefore, when someone mentions about character, it means having personality or manners, and having good character. A person with good character or good personality will do his/her best according to the views of religion, society, as well as the nation and state. Stedge defines a character as:

"Character is the culmination of habits, resulting from the ethical choices, behaviors, and attitudes an individual makes, and is the "moral excellence" an individual exhibits when no one is watching. "10

This definition explains that character is the culmination of habits resulting from ethical choices, behaviors, and attitudes that are owned by individuals who are prime morals, even when no one sees them. From this understanding, it can be understood that character includes a person's desire to do the best thing every time and wherever he/she is, without needing to be seen by others. His attitudes and actions are purely self-desired without any tendency. ${ }^{11}$

Fathul Muin defines character as a set of values that lead to the system, which underlies the thoughts, attitudes and behaviors that are displayed. Fathul Muin distinguishes character and personality. Personality can be understood as a dynamic organization of individuals in which the psychophysical system determines unique adjustments to their environment. Personality is behavior that is usually seen as a result of individual conditions and the structure of psychological situations. Meanwhile, character is related to the behavior patterns and actions in the way a person responds to situations that show certain consistency. ${ }^{12}$

In Arabic, character is similar to akhlak (the root word khuluk), which is the character or habit of doing good things. As Imam Ghazali considers that character is closer to morals, which is the behavior of a person that comes from a good heart. ${ }^{13}$ The same opinion was expressed by Marzuki that character is synonymous with morals, thus character is the universal value of human behavior which includes all human activities, both in relation to God, with oneself, with fellow humans, and with the environment that is manifested in the mind, attitudes, feelings, words and actions based on religious norms, law, manners, culture and customs. ${ }^{14}$ In the Qur'an, Allah says:

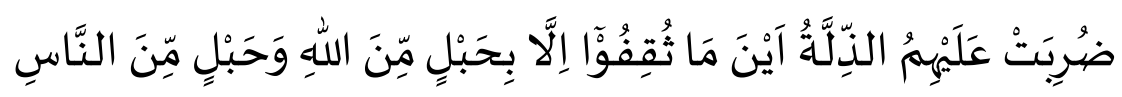

Translation:

"They are covered with humiliation wherever they are, unless they (hold) the rope (religion) of Allah and the rope (covenant) with humans."

\footnotetext{
${ }^{9}$ Kementerian Pendidikan Nasional, Pengembangan Pendidikan Budaya dan Karakter Bangsa (Jakarta: Kementerian Pendidikan Nasional, 2010), p. 3.

${ }^{10}$ Lauree Beth Stedge, Nuts and Bolts of Character Education (Edmond, Okhlahoma: Character First, 2010), p. 3.

${ }^{11}$ Arismantoro, Character Building, (Yogyakarta: Tiara Wacana, 2008), h. 27.

${ }^{12}$ Fathul Muin, Pendidikan Karakter: Konstruksi Teoritik dan Praktik (Yogyakarta: ar-Ruzz Media, 2011), pp. 33-40.

${ }^{13}$ Ratna Megawangi, Pendidikan Karakter; Solusi yang Tepat untuk Membangun Bangsa (Bogor: Indonesia Heritage Foundation, 2004), p. 25.

${ }^{14}$ Marzuki, Pengintegrasian Pendidikan Karakter Dalam Pembelajaran di Sekolah (Makalah. FIS Universitas Negeri Yogyakarta, 2011), p. 5
} 
Normatively, the character value in the Quran urges mankind to uphold human relations with the Creator and fellow humans as the basic concept of character values. The character values in the Qur'an can support the success of the world of education in educating students to have good morals. The inculcation of character values through PPKn learning is considered very important to solve national problems including religious, democratic, honest, national spirit, love for the country, and others.

\section{IV.INTEGRATION OF CHARACTER VALUES WITH PPKN LEARNING}

The fundamental problem at this time is that after the implementation of Pancasila and Citizenship Education (PPKn) learning, both at the school and university levels, the criminal rate among the younger generation in Indonesia is increasing. In fact, PPKn is the core of a subject that is considered capable of minimizing national problems. Therefore, we need an effort or strategic and methodological steps to overcome this problem. One of the efforts that needs to be done is the integration of character values, including religion and local values, into PPKn learning.

Inculcating character values through integrating in subjects through the introduction of values, will gain awareness of the importance of values, and internalize these values into students' daily behavior. ${ }^{15}$ Needless to say, all of the above will be carried out through the learning process in schools and colleges. Teaching is a part of education that refers to a broader and cross-cultural concept of a pluralistic society. ${ }^{16}$

Although education has a broader meaning than teaching, teaching is a very appropriate means of providing education. Therefore, the implementation of education must be based on a mature, clear and complete plan. The success of character education is largely determined by how to optimize the efforts of educators in planning and implementing, and evaluating the learning system. In Law No. 14 of 2005 on Teachers and Lecturers, article 20 paragraph 1 states that:

"In carrying out professional duties, teachers are obliged to plan learning, carry out a quality learning process, and assess and evaluate learning outcomes." 17

Based on the law above, learning as an activity process is essentially consists of three stages or phases. The phases of the learning process referred to are the planning stage, the implementation stage, and the evaluation or assessment stage. It is hoped that through these three stages character values can be integrated in the learning process, both inside and outside the classroom.

The Ministry of National Education (Kemendiknas) has formulated 18-character values that will be instilled in students as an effort to build national character. These character values are universal values that cover all religions, traditions and cultures of the Indonesian nation. These values must be the glue for all Indonesian people, even though they have different ethnic, religious and cultural backgrounds. These character values are: religious, honest, tolerance, discipline, hard work, creative, independent, democratic, curiosity, national spirit, love for the country, respect for achievement, friendly / communicative, peace-loving, fond of reading, caring for the environment. social care,

\footnotetext{
${ }^{15}$ Heri Gunawan, Pendidikan Karakter: Konsep dan Implementasi (Bandung: Alfabeta, 2014), p. 224.

${ }^{16}$ Syaiful Sagala, Konsep dan Makna Pembelajaran (Bandung: Alvabeta, 2008), p. 5.

${ }^{17}$ Departemen Pendidikan Nasional, Undang-Undang Nomor 14 Tahun 2005 Tentang Guru dan Dosen (Jakarta: Depdiknas, 2005),ph. 5
} 
and responsibility. ${ }^{18}$ These 18 -character values are integrated into Pancasila and Citizenship Education (PPKn) learning. The 18-character values are described in the following table:

\section{MAIN CHARACTERISTIC VALUES}

\begin{tabular}{|c|c|c|}
\hline No & Values & Description \\
\hline 1 & Religious & $\begin{array}{l}\text { Attitudes and behavior that are obedient in carrying out } \\
\text { the teachings of their religion, tolerant towards the } \\
\text { implementation of the worship of other religions, and } \\
\text { live in harmony with followers of other religions }\end{array}$ \\
\hline 2 & Honest & $\begin{array}{l}\text { Behavior based on efforts to make himself a person who } \\
\text { can always be trusted in words, actions, and work }\end{array}$ \\
\hline 3 & Tolerance & $\begin{array}{l}\text { Attitudes and actions that respect differences in } \\
\text { religion, ethnicity, ethnicity, opinions, attitudes, and } \\
\text { actions of others who are different from oneself }\end{array}$ \\
\hline 4 & Discipline & $\begin{array}{l}\text { Actions that show orderly behavior and comply with } \\
\text { various rules and regulations. }\end{array}$ \\
\hline 5 & Hard work & $\begin{array}{l}\text { Behavior which shows serious efforts in overcoming } \\
\text { various obstacles to learning and assignments, and } \\
\text { completing tasks as well as possible }\end{array}$ \\
\hline 6 & Creative & $\begin{array}{l}\text { Thinking and doing something to produce a new way or } \\
\text { result from something that is already owned. }\end{array}$ \\
\hline 7 & Independent & $\begin{array}{l}\text { Attitudes and behaviors which are not easy to depend } \\
\text { on other people to complete tasks }\end{array}$ \\
\hline 8 & Democratic & $\begin{array}{l}\text { A way of thinking, having a perspective, and acting that } \\
\text { values the rights and obligations of oneself and others. }\end{array}$ \\
\hline 9 & Curiosity & $\begin{array}{l}\text { Attitudes and actions that always seek to know more } \\
\text { deeply and extensively from something they have } \\
\text { learned and others. }\end{array}$ \\
\hline 10 & National spirit & $\begin{array}{l}\text { A way of thinking, acting, and having an insight that } \\
\text { places the interests of the nation and the State above the } \\
\text { interests of themselves and their groups. }\end{array}$ \\
\hline 11 & Love the homeland & $\begin{array}{l}\text { A way of thinking, behaving and acting that shows } \\
\text { loyalty, concern, and high respect for the nation's } \\
\text { language, physical, social, cultural, economic and } \\
\text { political environment. }\end{array}$ \\
\hline 12 & $\begin{array}{l}\text { Appreciating } \\
\text { Achievements }\end{array}$ & $\begin{array}{l}\text { Attitudes and actions that encourage him to produce } \\
\text { something useful for society, and recognize and respect } \\
\text { the success of others. }\end{array}$ \\
\hline 13 & $\begin{array}{l}\text { Friendly / } \\
\text { communicative }\end{array}$ & $\begin{array}{l}\text { Actions that show a sense of pleasure to talk, socialize, } \\
\text { and cooperate with others. }\end{array}$ \\
\hline 14 & Peace-loving & $\begin{array}{l}\text { Attitudes, words, and actions that cause others to feel } \\
\text { happy and secure in their presence. }\end{array}$ \\
\hline 15 & Love to read & $\begin{array}{l}\text { The habit of taking time to read various texts that are } \\
\text { good for him/her }\end{array}$ \\
\hline
\end{tabular}

${ }^{18}$ Hartono, Pendidikan Karakter dalam Kurikulim 2013, Jnana Budaya. Vol. 19, No 2, Agustus 2014, p. 262. 


\begin{tabular}{|l|l|l|}
\hline 16 & $\begin{array}{l}\text { Caring for the } \\
\text { environment }\end{array}$ & $\begin{array}{l}\text { Attitudes and actions that always seek to prevent } \\
\text { damage to the surrounding natural environment, and } \\
\text { develop efforts to repair natural damage that has } \\
\text { occurred. }\end{array}$ \\
\hline 17 & $\begin{array}{l}\text { Attitudes and actions that always want to provide } \\
\text { assistance to other people and communities in need }\end{array}$ \\
\hline 18 & Responsibility & $\begin{array}{l}\text { Attitudes and behavior of a person to carry out his } \\
\text { duties and obligations that he should do to himself, } \\
\text { society, the environment (natural, social, and cultural), } \\
\text { the State and TYME. }\end{array}$ \\
\hline
\end{tabular}

Source: Ministry of National Education Research and Development Curriculum Center 2010 .

To achieve the goal of inculcating character values in PPKn learning, there are three stages in the process that must be passed, namely planning, implementation and assessment. According to Charles Diebold et al, learning planning is related to the setting of learning objectives through theoretical and empirical foundations. The implementation of learning is related to learning strategies, module use, instructional media, design and learning methods in the teaching process. Learning assessment is related to calibration, correction and evaluation of learning outcomes to determine the achievement of learning objectives. ${ }^{19}$

The integration of character education in the learning process is carried out starting from the planning, implementation, and evaluation / assessment stages of learning. In the implementation stage, the syllabus, lesson plans, and teaching materials should be designed in such a way that the content and activities in the learning process are character-based. Likewise, in the implementation of learning activities which include the stages of preliminary activities, core activities, and closing activities carried out in such a way so that students practice the targeted character values. In the evaluation stage, the selected and implemented assessment techniques and instruments should not only measure students 'cognitive achievement, but also measure students' personality development.

In fact, the character values that are integrated in all subjects are not taught in the form of knowledge, except in the subject of Religion. Religious subjects, which contain teachings, are still taught in the form of processes, knowing, doing, and finally habit. Try to make the learning process carried out by students in an active and fun way (enjoy full learning). This process shows that the implementation of learning in character content is carried out by students, while the teacher applies the tut wuri handayani principle in every student's behavior. ${ }^{20}$

The following is the process of integrating character values in learning which is carried out in three stages of implementation, namely through the planning, implementation, and evaluation / assessment stages:

\footnotetext{
${ }^{19}$ Charles Diebold dkk., Building an Intervention: A Theoretical and Practical Infrastructure for Planning, Implementing, and Evaluating a Metropolitan-Wide School-To- Career Initiative, Journal of Educational and Psychological Consultation, Vol.11, No. 1, 2012, p. 149.

${ }^{20}$ Dasyim Budimasyah, Penguatan Pendidikan Kewarganegaraan untuk Membangun Karakter Bangsa (Bandung: Widya Aksara Press, 2010), p. 68.
} 


\section{A. PPKn Lesson Planning}

Planning is very important before carrying out activities. Kristian Oleson said that planning theory offers a framework of thought and a series of frames for looking at planning practice in order to raise students' awareness and help them reflect on their own values. ${ }^{21}$ Yibin Zhang \& Diana Laurillard illustrate an example of a teaching plan in a Chinese language course, where teachers try to foster students' reading skills through guided reading activities. First of all, students read the reading material, and try to understand in general terms the ideas that exist. At the same time, the teacher held several group discussions. Next, students focus on the breakdown of the passage through learning new words and key expressions from the text with further exposure to relevant language input at the same level as various exercises in listening or reading. Lastly contains some simulated communication exercises. ${ }^{22}$

Maria Magdalena Isac et al said that planning for learning in civic education, there are three components in improving the quality of students, namely; grouping procedures, material curriculum, and teacher behavior, while considering the structure of the level of learning of students in schools. Student and student achievement is influenced by social background, intelligence, motivation, time they study, and how they use learning opportunities. The learning time factor and the opportunity to learn are provided in the classroom under the direction of teachers and lecturers. ${ }^{23}$ From some of the descriptions above, it can be concluded that learning planning is an activity of a teacher or lecturer in designing or preparing everything in the learning process, such as syllabus and lesson plans (RPP / RPS). In the RPP / RPS, the PPKn teacher or lecturer considers the views of experts on the motivation and level of intelligence of students or students, prepares reading material for students, generally understands student ideas, conducts group discussions, fosters student interest in reading, directs in understand the values of PPKn, and motivate students to practice the values of PPKn in everyday life.

\section{B. Implementation of PPKn Learning}

The implementation of PPKn is at the core of the integration of education in PPKn learning. The implementation of PPKn learning is to carry out the planning results that have been made in the syllabus and lesson plans through the chosen teaching method so that the learning objectives can be achieved. The implementation of this PPKn learning begins with an introduction, core and ends with a closing. In implementing PPKn learning, several components are needed. Wina Sanjaya said there are several components in the implementation of PPKn learning that need to be considered, among them: learning objectives and materials, learning methods or strategies, media and evaluation. If the components mentioned above are implemented properly, the learning process will be directed towards the learning objectives so that the motivation of educators and students in the teaching and learning process can increase properly. ${ }^{24}$

\footnotetext{
${ }^{21}$ Kristian Olesen, Teaching Planning Theory as Planner Roles in Urban Planning education, Higher Education Pedagogies, Vol. 3, No. 1, 2018, p. 26.

${ }^{22}$ Yibin Zhang dan Diana Laurillard, Planning and Sharing Learning Designs: Cross-Cultural Use of a Learning Design Support Tool, Learning: Research and Practice, 1:2, 2015, p. 155.

${ }^{23}$ Maria Magdalena Isac dkk., Effective civic education: an educational effectiveness model for explaining students' civic knowledge. School Effectiveness and School Improvement, Vol. 22, No. 3, September 2011, p. 314

${ }^{24}$ Wina Sanjaya. Strategi Pembelajaran: Berorientasi Standar Proses Pendidikan, (Jakarta: Kencana Prenada Media Group, 2009), p. 58
} 
In an effort to strengthen the implementation of the integration of character education that is integrated from religious teachings, Pancasila, culture, and national education goals, there are 18 values that can be understood and implemented by students during the learning process, including: religious, honest, tolerant, disciplined, work hard, creative, independent, democratic, curiosity, national spirit, love the country, respect for achievement, friendly / communicative, love peace, love to read, care for the environment, care for social, responsibility. ${ }^{25}$

The integration of character education contained in the syllabus and lesson plans which contain the 18 values mentioned above will be carried out during the learning process. Through knowledge, experience and learning methods applied by PPKn teachers, it is hoped that these character values can be understood and implemented properly by students in everyday life.

\section{Evaluation of PPKn Learning}

After carrying out the PPKn learning, an evaluation is needed to see and ensure whether the PPKn lesson is in accordance with the PPKn learning objectives or not. The evaluation of PPKn learning is very important to be carried out to determine the extent to which the students' absorption of understanding during the learning implementation, to know the level of sensitivity to the character values learned during one semester, and to what extent they apply these character values both in class and outside the classroom. Evaluation is carried out on an ongoing basis to monitor students in their involvement in positive things, for example, polite in speaking, like to help friends, honest, responsible and others. Likewise, with negative things, it is hoped that students can avoid it, for example fights between friends or between schools, smoking, drinking alcohol, and others. It needs to be realized that every learning implementation has obstacles, including in PPKn learning. Chi - Kim Cheung and Margaret Leung said that implementing PPKn experienced several difficulties, including:

1. There were misconceptions on the part of some teachers about civic education;

2. Wowing to the heavy commitments in teaching the subject syllabuses, very little time could be spared for introducing civic education elements in class;

3. Suitable teaching/resource materials were difficult to obtain; and

4. If it was difficult to arouse pupils' interest in civic education. ${ }^{26}$

The challenge described by Chi - Kim Cheung and Margaret Leung above is a common symptom in every implementation of PPKn learning. Therefore, teachers or lecturers who teach PPKn must improve themselves in increasing the quality of mastery of the appropriate PPKn material and teaching methods in order to minimize the challenges faced by the Indonesian nation.

\section{CONCLUSION}

From the description above, there are several conclusions related to the integration of character values into PPKn learning in an effort to strengthen national morale, including: 1. There are 18 character values that are integrated into PPKn learning,

\footnotetext{
${ }^{25}$ Kementrian Pendidikan Nasional, Pengembangan dan Pendidikan Budaya dan Karakter Bangsa: Pedoman Sekolah. 20011 p. 8

${ }^{26}$ Chi-Kim Cheung a \& Margaret Leung, From Civic Education to General Studies: The Implementation of Political Education into the Primary Curriculum, Compare: A Journal of Comparative and International Education, Vol. 28, No. 1, 1998, p. 50.
} 
including: religious values, honesty, tolerance, discipline, hard work, creative, independent, democratic, curiosity, national spirit, love of the country, respect for achievement, friendly / communicative , peace-loving, fond of reading, environmental care, social care, and responsibility. 2. The integration of character values in PPKn learning is carried out in three stages of implementation, namely through the planning, implementation, and evaluation / assessment stages. If these three stages are carried out properly by the PPKn teachers, then the application of character values in PPKn learning will work well.

\section{REFERENCES}

Arismantoro, Character Building, Yogyakarta: Tiara Wacana, 2008.

Bertens, K. Etika. Jakarta: PT Gramedia Pustaka Utama, 2005.

Budimasyah, Dasyim. Penguatan Pendidikan Kewarganegaraan untuk Membangun Karakter Bangsa Bandung: Widya Aksara Press, 2010.

Cheung, Chi-Kim a \& Margaret Leung, From Civic Education to General Studies: The Implementation of Political Education into the Primary Curriculum, Compare: A Journal of Comparative and International Education, Vol. 28, No. 1, 1998, pp. 4756.

Darajat, Zakiyah. Dasar-Dasar Agama Islam. Jakarta: Bulan Bintang, 2007.

Departemen Pendidikan Nasional, Undang-Undang Nomor 14 Tahun 2005 Tentang Guru dan Dosen. Jakarta: Depdiknas, 2005.

Diebold, Charles dkk., Building an Intervention: A Theoretical and Practical Infrastructure for Planning, Implementing, and Evaluating a Metropolitan-Wide School-To- Career Initiative, Journal of Educational and Psychological Consultation, Vol.11, No. 1, 2012, pp. 147-172.

Gazalba, Sidi. Sistematika Filsafat, Buku Kedua: Pengantar kepada Teori Nilai. Jakarta: Bulan Bintang, 2002.

Gunawan, Heri. Pendidikan Karakter: Konsep dan Implementasi. Bandung: Alfabeta, 2014.

Hartono, Pendidikan Karakter dalam Kurikulim 2013, Jnana Budaya. Vol. 19, No 2, Agustus 2014, pp. 259 - 268

Isac, Maria Magdalena dkk., Effective civic education: an educational effectiveness model for explaining students' civic knowledge. School Effectiveness and School Improvement, Vol. 22, No. 3, September 2011, pp. 313-333.

Kementerian Pendidikan Nasional, Pengembangan Pendidikan Budaya dan Karakter Bangsa. Jakarta: Kementerian Pendidikan Nasional, 2010. 
Kementrian Pendidikan Nasional, Pengembangan dan Pendidikan Budaya dan Karakter Bangsa: Pedoman Sekolah. 20011.

Marzuki, Pengintegrasian Pendidikan Karakter Dalam Pembelajaran di Sekolah. Makalah. FIS Universitas Negeri Yogyakarta, 2011.

Megawangi, Ratna. Pendidikan Karakter; Solusi yang Tepat untuk Membangun Bangsa Bogor: Indonesia Heritage Foundation, 2004.

Muin, Fathul Pendidikan Karakter: Konstruksi Teoritik dan Praktik. Yogyakarta: ar-Ruzz Media, 2011.

Narmoatmojo, Winarno. Pendidikan Nilai di Era Global. (Paper Presented in Regional Seminar "Implementasi Pendidikan Nilai di Era Global" 22 September 2010 in Postgraduate Building of UNISRI Surakarta.

Olesen, Kristian. Teaching Planning Theory as Planner Roles in Urban Planning education, Higher Education Pedagogies, Vol. 3, No. 1, 2018, pp. 23-39.

Qutoshi, Sadruddin Bahadur. Phenomenology: A Philosophy and Method of Inquiry, Journal of Education and Educational Development, Vol. 5, No. 1, June 2018, p. 215

Sagala, Syaiful. Konsep dan Makna Pembelajaran. Bandung: Alvabeta, 2008.

Sanjaya. Wina. Strategi Pembelajaran: Berorientasi Standar Proses Pendidikan. Jakarta: Kencana Prenada Media Group, 2009.

Stedge, Lauree Beth. Nuts and Bolts of Character Education. Edmond, Oklahoma: Character First, 2010.

Subagyo, Joko. Metode Penelitian dalam Teori dan Praktek. Jakarta: Renika Cipta, 1991.

Toha, Chabib. Kapita Selekta Pendidikan Islam. Yogyakarta: Pustaka Pelajar, 2006.

Zhang, Yibin dan Diana Laurillard, Planning and Sharing Learning Designs: CrossCultural Use of a Learning Design Support Tool, Learning: Research and Practice, 1:2, 2015, pp. 152-161.

Zuchdi, Darmiyati dkk, Pendidikan Karakter dengan Pendekatan Kompehensif. Cet. 1; UNY Press, 2010. 